\title{
An Investigation of Basic Aspects of the Quranic Miracle
}

\author{
Hassan Rezaee Haftador ${ }^{1}$ \\ ${ }^{1}$ Hadith and Qur'anic Sciences Department, Tehran University, Tehran, Iran \\ Correspondence: Hassan Rezaee Haftador, Hadith and Qur'anic Sciences Department, Tehran University, \\ Tehran, Iran. E-mail: hrezaii@ut.ac.ir
}

Received: January 12, 2015 Accepted: January 26, 2015 Online Published: March 16, 2015

doi:10.5539/ass.v11n7p38

URL: http://dx.doi.org/10.5539/ass.v11n7p38

\begin{abstract}
The Quranic miracle is an important issue in Quranic studies and Islamic philosophy (kalām) that provides evidence for the miraculousness of the Quran. Muslim scholars have presented wide-ranging discourses on the basic aspects of the Quranic miracle. Three basic aspects have been propounded by scholars including literary, legislative, and scientific miraculousness, each of which is discussed in the present study. Even though the Quran consist of common letters and words in the Arabic language, the eloquence (fașăhat wa balagghat) and unique placement of words in the Quran are miraculous. The special style of the Quran is neither poetry, nor prose, not

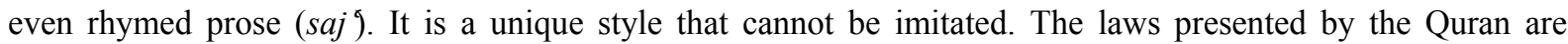
comprehensive, complete, and based on rational principles. The scientific miracle of the Quran relates to scientific truths that exist in some verses of the Quran though enumeration of these truths is not the main purpose. This is because the Quran is a book of guidance, and its main purpose is to direct the course of human lives and show the path to eternal happiness, not to discuss scientific matters.
\end{abstract}

Keywords: The Quran, literary miracle, legislative miracle, scientific miracle

\section{Introduction}

Throughout history, humans have encountered extraordinary deeds by special people. These extraordinary acts have inspired the wonder and admiration of humanity, both giving and destroying faith. Prophets of God would call these extraordinary acts 'miracles' and challenge others to perform similar acts if they were able. Prophets considered these acts to be evidence of the truth of their prophethood.

In contrast to these righteous men, others existed who performed extraordinary acts called 'sorcery'. Sometimes, people could not distinguish which was the truth. Therefore, opponents of divine religions would accuse prophets of being sorcerers. The precise date of the first miracle is not known. However, prophets of God usually had miracles, as the people would ask every new prophet to provide a miracle.

The Quran is a miracle of Muhammad, the Prophet of Islam. Some of its verses challenge humans to compose something similar (Ṭabrisī, 1986; Ālūsī, 1994; Zamakhsharī, 2006; Rāzī, 2000). Thus, utilising a descriptive and analytic approach, the present paper seeks to answer the question, 'In what aspects is the Quran a miracle?'

\section{Terminological Definition of I $\mathfrak{j} \overline{j a ̄ z}$ (Miracle)}

In Arabic, $i_{j} \bar{a} z$ means to make unable (Atābakī, 2001). This can happen in two ways. One is that the ability of a person is taken away by force, making the person incapable. For instance, the term can be used where the wealth or position of a person is wrested away. The other way is for an act to be performed that others are unable to do or match, without any negative action against others. By way of example, a person can achieve spiritual perfection to extent that no one else can reach. The $i j \bar{a} z$ of the Quran is of the latter type. To explain, in terms of eloquence, stability of speech, coherence, and innovations in thought, commandments, and other features, the Quran is far beyond anything attainable by human beings. Thus, the Quran is considered the eternal miracle. This miraculousness is everlasting and constant since this divine book is the document of the eternal religion of Islam (Ma rifat, 2005; Zarqānī, 1991).

\section{Aspects of the Quranic Miracle}

Thinkers have presented comprehensive discourses on the Quranic miracle. Naturally, there are different opinions in this regard. The thought of ancient and contemporary scholars differ somewhat, and later scholars have added to the ideas of the ancients (Ma'rifat, 2005). 
Today, three basic aspects of the Quranic miracle are discussed including literary, legislative, and scientific miraculousness. Each of these is referred to in the following discussion.

\subsection{Literary Miracle}

The literary miracle refers to verbal aspects, terms, literary elegance, and eloquence (Bāqillānī, 2005).

The literary miracle of the Quran may be discussed in five categories.

\subsubsection{Choice of Words}

The choice of words in Quranic phrases is meticulously calculated such that no word in the Quran can be substituted for any other word while preserving all the qualities of the original word in that particular placement. Several issues have been considered regarding the selection of Quranic words.

a. Vocal symmetry of contiguous words such that the last letter of each word is harmonious with the first letter in the next word.

b. Semantic congruity of words making the text coherent.

c. Observance of the rules of eloquence ( $f a s ̦ a ̣ h a t)$ according to the discipline of rhetoric ( $m a$ ànī bayān).

These three criteria take into consideration the features of every word. In this way, every word is placed in its own special place in the best possible manner (Jurjān̄i, 1998).

The meticulousness of the Quran in selection of words is based on two main conditions.

a. Complete and comprehensive knowledge of word features such that the features of every single word are known in relation to all other words.

b. Perpetual mindfulness: when words are being employed, all words must be present in the mind of the speaker so there is no confusion in the selection of words.

It seems impossible for a normal person to have both these criteria (Zarkishī, 1956; Márifat, 1989).

\subsubsection{Style and Expression}

Even though the form of the Quran attracted the Arab people, it bore no similarity to popular styles and forms of the time (Qurțubī, 1994; ibn Ḥajar 'Asqalānī, 2003; Ghazzālī, 2007; Shahristānī, 1951; Suyūṭī, 1991).

It is a wonder of eloquence for an orator to create a completely new style that is not only acceptable for the audience but also savoury. It is an even greater wonder if this new method utilises all conventional techniques of rhetoric and eloquence without having any of the limitations of these techniques.

The three common text types among Arab rhetoricians include poetry, prose, and rhymed prose. Each of these text types has strong points and drawbacks. The Quranic style enjoys the charm and elegance of poetry, the absolute freedom of prose, and the beauty and gentleness of rhymed prose without being fettered to metre and $q \bar{a}$ fiyah (i.e. the final rhyming syllable in a verse) (a limitation of poetry), rambling (a fault of prose), or abstruseness (a limitation of rhymed prose). This beautiful blend of features brought about the admiration and wonderment of Arab rhetoricians (Khū̄î̀, 1974; Márifat, 1989; Mīr Muḥammadī, 1995).

\subsubsection{Rhythm of the Quran}

When listening to the Quran, the first thing that captures one's attention is the exquisite rhythm. In this system, the vowels and consonants of the words are arranged in a manner that is pleasing to the ear. Its melody invigorates the heart and vitalises the soul. It is the orderly rhythm of the Quran that arouses sentiments and captivates hearts (Darrāz, 2009).

External music is a product of literary devices such as rhyme and metre. However, 'inner rhythm', which is specific to the Quran, is a result of the profound significance and magnificence of the essence of Quranic verses. The aesthetic appeal of the words and the brilliance of the meaning shape an inspiringly resonant euphony. Inner rhythm is a secret of the Quran, and no literary composition can equal it (Márifat, 1989).

\subsubsection{Thematic Unity}

The verses of the Quran have been revealed in a dispersed manner and for a variety of occasions. Naturally, there need not be any relationship or congruence between these verses. Nonetheless, by analysing the content of each chapter of the Quran, especially in the modern era, scholars have found that each chapter follows a specific purpose or set of purposes inclusive of all the verses of the respective chapter. This is one aspect of the miracle (Sayyid ibn Quțb, 1991). This contextual unity that exists in every chapter of the Quran is called 'thematic unity' (Ma'rifat, 2009). 


\subsubsection{Subtle Details}

The Quran makes extensive use of metaphors, similes, allusions, and subtle details. In every case, Arabic conventions have been observed. However, the precision employed in them have elicited wonder in Arab rhetoricians. Arab masters of oratory acknowledge that the similes in the Quran are the most graceful similes in Arabic literature. They profess that the Quran utilises the highest form of expression in the clearest possible manner (ibn Athīr, 1939; Ma'rifat, 2009).

\subsection{Legislative Miracle}

Humans have always had questions about the universe and the secret of creation and have continually endeavoured to discover convincing answers to them. Some of these questions relate to where we have come from, why, and where we are going. Human endeavours to discover the secret of creation have been unable to provide a convincing answer and to clarify the totality of the matter (Maybudī, 1993; Jurjān̄i, 1998).

The religion of Islam - as presented by the Quran - gives adequate responses to all such questions. By contemplating what the Quran has to offer, deviation in thought is mitigated and development may continue (Bayḍāwī, 1998; Ṭūsī, 1982; Khū’̀̄, 1974).

The Quran provides humans with the object of their search. It offers them what they could not clearly achieve by themselves, and this is another aspect of its miracle. If not for this blessing, humanity could never reach its objective.

People living before Islam, whether the most primitive tribes or the most civilised societies, had beliefs about the universe, the origin of creation, and predestination that were closer to fantasies than reality. The sayings of prophets were distorted over time so humans could not correctly know where they came from, why, and where they were going. But then the Quran provided clear, decisive answers in all these areas. The laws presented by the Quran are free of superstition and based on rational principles (Iskandarlū, 2011; Márifat, 2009).

The guidelines established by the Quran assure a healthy society and happy lives for humans besides strengthening people's relationships with their Lord and the world beyond this mundane existence.

In this world, humans endeavour towards their personal interests, but they are also necessarily linked with social interests, which they must take into consideration as well. We live our lives beside other people and cannot think only of our personal interests. Social life is a life of transactions that must be respected. Observance of social transactions can only successfully occur through the rule of law.

Human laws can only regulate personal and social life. They limit the freedom of people in public and private affairs to prevent people from infringing upon the rights of others as well as failing to carry out their responsibilities. However, humans have a third dependency in their lives; that is, their relationship with God and the hereafter. If this relationship is solid, it prevents a person from indulgence and excess, helping the individual practice moderation (Ibn Shahr Āshūb Māzandarānī, 1989; ibn Kathīr Dimishqī, 1998; Qurțubī, 1985).

On this basis, all divine commandments established in the Quran are three dimensional. In other words, personal and public affairs as well as the relationship with God and spirituality - which safeguards human dignity - are all taken into consideration in these commandments (Iskandarlū, 2011).

It is an aim of the Quran to secure happiness in this life as well as eternal happiness in the next world, whereas even where secular laws are sincere and free of bias and deviation; they are bereft of the third dimension of human life. This three-dimensional aspect of Quranic commandments demonstrates that it is a miracle beyond human competence (Macrifat, 2005). Human laws legislated by individuals or parliaments usually have problems and oversights that manifest themselves over time. Thus, human laws periodically require revision, supplementation, and reform, and sometimes the law must be changed entirely. Some reasons for this are as follows.

a. Humans do not posses comprehensive knowledge about the world or even the needs of individuals and societies and, therefore, cannot take all worldly and otherworldly affairs into consideration.

b. The limited, personal desires and motives of human beings habitually affect their decisions.

c. Human thought is subject to error. Therefore, even with good intentions, mistakes may be made in legislation of laws.

Accordingly, human-made laws are susceptible to deviation and error, and cannot be complete. However, the laws of the Quran have been issued from an entity that has the following characteristics. 
a. He possesses comprehensive knowledge of the entire world, including the needs of individuals and societies both in this world and the next.

b. His decisions are wise and not prone to carnal desires.

c. He is not vulnerable to error.

Laws issued by this God are based on perfect knowledge and are free of deviation or error. Consequently, the laws of the Quran are complete and correct, and the best possible laws. Over fourteen centuries have passed since their inception, but they are not outdated and do not require alteration, revision, or reform (Ișfahān̄̄, 2013).

The role of the Quran in the social and cultural development of the Arabs as well as alteration of their rules and conventions was miraculous. No human book can create such a historical change in the culture and laws of a nation. The legislative miracle of the Quran was able to bring a revolution not only to the Arab society, but to human civilisation as a whole by replacing the laws of the era of Ignorance, which were inhuman and antagonistic to science and reason, with lofty laws corresponding to reason, justice, science, and human nature (Khū̄ò, 1974; Riḍ̂̄̄̄i Ișfahān̄̄, 2013).

\subsection{Scientific Miracle}

The scientific miracle of the Quran refers to the scientific details presented in some Quranic verses. It must be noted that presentation of these details is not the primary purpose of the Quran as the Quran is a book of guidance. Its central purpose is to direct the lives of human beings and enlighten them about the path to happiness, not to discuss scientific issues. Hence, the reason for these references in the Quran is that these statements have originated from and represent the boundless source of knowledge and wisdom (Tabarī, 1991; Abū al-Futūḥ Rāzīi, 1988).

There are many scientific references in the Quran (Ma'rifat,, 2005; Rị̣̂̄̄̄ Ișfahānī, 2004) and only those who dedicate meticulous attention to Quranic verses comprehend these secrets and passing references. For scientists, these details are grounds for the miraculousness of the Quran. Some of these references were discovered early, but others have only become clear recently with modern science. Perhaps further references will be found in the future. Scientists have endeavoured greatly in this area, especially in modern times. Although some have committed errors in this regard, many have been successful. There are in excess of two thousand verses in the Quran involving scientific references in the natural sciences, such as medicine, geology, biology, and astronomy as well as the humanities including teaching, economics, politics, and management. It must be stressed that scientific findings must not be imposed upon the Quran since such findings are not stable, whereas the Quran is comprised of firm truths. One must never attempt to coordinate or match something changeable with an unwavering truth. Scientific truths that have attained stability and certainty can be used as means to understand scientific references in the Quran, not with absolute conviction but in conjunction with terms such as 'perhaps' and 'it may be so'. In this way, when scientific theories previously assumed to be infallible are proven wrong, it will not harm the strength and stability of the Quran (Ma'rifat, 2005; Iskandarlū, 2011).

\section{Conclusions}

Literary, legislative, and scientific miracles are the most important aspects of the Quranic miracle. The choice of words in Quranic phrases is made with meticulous intent such that no word in the Quran can be substituted for any other word while still preserving all the qualities of the original word in its particular placement. Even though the form of the Quran attracted the Arab people, it bore no similarity to popular styles and forms of the time. In this system, the vowels and consonants of Quranic words are arranged in a manner that is pleasing to the ear. Its melody invigorates the heart and vitalises the soul. Arab masters of oratory acknowledge that the similes in the Quran are the most graceful similes in Arabic literature. They profess that the Quran utilises the highest form of expression in the clearest possible manner. The existence of miraculous laws in the Quran, its peerless system of legislation, and the miraculous influence of the Quran in altering the laws of the ignorant Arab society compose the legislative miracle of the Quran. Prior to the Quran, no book had such influence and after its presentation to the world, no human being has been able to bring its like in these three aspects. Some Quranic verses include scientific references that are miraculous in their correspondence to modern scientific findings.

\section{References}

Abu al-Futuh Razi, Ḥusayn ibn 'Ali (1988). In M. J. Yaḥaqqi (Ed.), Rawḍ al-Jinan wa Ruḥ al-Jinan fi Tafsir al-Qur'an (Vol. 14, p. 195). Mashhad: Bunyad Pizhuhishha Islami Astan Quds Raḍavi.

Alusi, M. (1994). Ruh al-Ma'ani fi Tafsir al-Qur'an al-'Azim wa al-Sab'al-Mathani, ed. 'Ali 'Abd al-Bari 'Ațiyyah (Vol. 6, pp. 111-112). Beirut: Dar al-Kutub al-'Ilmiyyah. 
Atabaki, P. (2001). Farhang Jami 'Karburdi Farzan (Vol. 1, p. 382). Tehran: Nashr va Pazhuhish Farzan Ruz. Baydawi, 'A. A. (1998). Anwar al-Tanzil wa Asrar al-Ta wil (Vol. 3, p. 116). Dar Ihya' al-Turath al-'Arabi. Baqillani, M. ibn Ț. (2005). Ijaz al-Qur'an (p. 57). Beirut: Dar al-Jil.

Darraz, 'A. A. (2009). Al-Naba' al- 'Azim (pp. 94-99). Cairo: Maktabah al-Tawfiqiyyah.

Ghazzali, M. ibn M. (2007). Ihya' Ulum al-Din (Vol. 1, p. 281). Beirut: Al-Maktabah al-'Așriyyah.

Ibn Athir, N. A. ibn M. (1939). In Muḥammad Muhy al-Din 'Abd al-Ḥamid (Ed.), Al-Mathal al-Sa ir fi Adab al-Katib wa al-Sha ir (Vol. 2, pp. 126-135). Cairo: Maktabah wa Mațba'ah Musțafa al-Babi al-Halabi.

Ibn Ḥajar 'Asqalani, A. ibn ‘A. (2003). Al-Ișabah fi Tamyiz al-Ṣahabah (Vol. 1, p. 410). Mu’assisah al-Risalah.

Ibn Kathir Dimishqi, I. (1998). Tafsir al-Qur'an al- Azim (Vol. 3, p. 61). Beirut: Dar al-Kutub al-'Imliyyah.

Ibn Shahr Ashub Mazandarani. (1989). Mutashabih al-Qur'an wa Mukhtalifah (Vol. 1, p. 130). Qum: Bidar.

Iskandarlu, M. J. (2011). Ijaz Qur'an va Mașuniyat az Taḥrif (pp. 112-114). Qum: Markaz Bayn al-Milali Tarjumah va Nashr al-Mustafa.

Jurjani, Ḥ. ibn Ḥ. (1998). Jala'al-Adhhan wa Jala'al-A ḩzan (Vol. 5, p. 334). Tehran: Intisharat Danishgah.

Khu'i, A. al-Q. (1974). Al-Tibyan fi Tafsir al-Qur'an (pp. 48-49). Qum: Al-Mațba'ah al-'Ilmiyyah.

Márifat, M. H. (2009). Amuzish Ulum Qur'ani (p. 169). Qum: Mu’assisah Farhangi Tamhid.

Ma'rifat, M. H. (1989). Al-Tamhid fi 'Ulum al-Qur'an (Vol. 4, pp. 41, 80, 129-132). Qum: Markaz Mudiriyat Hawzah 'Ilmiyyah Qum.

Márifat, M. H. (2005). Ulum Qur'ani (pp. 287-288). Qum: Mu’assisah Farhangi Tamhid.

Maybudi, R. Al-D. (1993). Kashf al-Asrar wa Uddah al-Abrar (Vol. 5, pp. 613-614). ed. 'Ali Asghar Hikmat, Tehran: Intisharat Amir Kabir.

Mir Muhammadi, A. al-F. (1995).Tarikh va Ulum Qur'an (p. 200). Qum: Daftar Intisharat Islami.

Qurțubi, M. ibn A. (1985). Al-Jami 'li-Ahkam al-Qur'an (Vol. 6, p. 118). Tehran: Intisharat Nașir Khusraw.

Qurțubi, Y. ibn 'A. al-B. (1994). Al-Istíab fi Ma'́rifah al-Așhab (Vol. 1, p. 412). Beirut: Dar al-Kutub al-'Ilmiyyah.

Razi, F. al-D. (2000). Mafatịh al-Ghayb (Vol. 28, p. 215). Beirut: Dar Ihya' al-Turath al-'Arabi.

Rị̣a’i Ișfahani, M. 'A. (2004). Daramadi bar Tafsir Ilmi Qur’an (pp. 422-432). Qum: Uswah.

Rị̣a’i Ișfahani, M. 'A. (2013). Ijaz Qur’an dar Ulum Tabi i va Insani (pp. 469-470). Qum: Markaz Bayn al-Milali Tarjumah va Nashr al-Mustafa.

Sayyid ibn Quțb, I. (1991). Al-Tașwir al-Fanni fi al-Qur'an (p. 69). Beirut: Dar al-Shuruq.

Shahristani, H. al-D. (1951). Al-Mu jizah al-Khalidah (p. 21). Kaẓimayn: Maktabah al-Jawadayn al-'Ammah.

Suyuți, 'A. al-R. (1991). Al-Durr al-Manthur fi al-Tafsir al-Ma thur (Vol. 6, p. 283). Dar al-Kutub al-'Ilmiyyah.

Țabrisi, F. ibn H. (1986). Majma 'al-Bayan li- Ulum al-Qur'an (Vol. 6, p. 676). Beirut: Dar al-Márifah.

Tabari, M. ibn J. (1991). Jami 'al-Bayan 'an Ta wil Ay al-Qur'an (Vol. 18, p. 138). Beirut: Dar al-Ma'rifah.

Țusi, M. ibn H. (1982). In S. A. Tihrani, \& A. Q. ‘Amili (Eds.), Al-Tibyan al-Jami ‘li-Ulum al-Qur'an (Vol. 5, p. 395). Beirut: Dar Ihya' al-Turath al-'Arabi.

Zamakhshari, M. (2006). Al-Kashshaf 'an Haqayiq Ghawamid al-Tanzil wa Uyun al-Aqawil fi Wujuh al-Ta wil (Vol. 2, p. 383). Beirut: Dar al-Kitab al-'Arabi.

Zarqani, 'A. al-'A. (1991). Manahil al- Irfan fi Ulum al-Qur'an (Vol. 2, p. 227). Mu'assisah al-Tarikh al-'Arabi.

Zarkishi, B. al-D. (1956). Al-Burhan fi Ulum al-Qur'an (Vol. 2, p. 97). Beirut: Dar Ihya' al-Kutub al-'Arabiyyah.

\section{Copyrights}

Copyright for this article is retained by the author(s), with first publication rights granted to the journal.

This is an open-access article distributed under the terms and conditions of the Creative Commons Attribution license (http://creativecommons.org/licenses/by/3.0/). 